\title{
Self-care convicting adverse reaction: prednisolone instance
}

\section{Pamayyagari Kalpana*}

Department of Pharmacy Practice, Annamacharya College of Pharmacy, Rajampeta, Andhra Pradesh, India

Received: 10 June 2020

Revised: 09 July 2020

Accepted: 10 July 2020

\section{*Correspondence:}

Dr. Pamayyagari Kalpana,

Email: pkalpana3366@gmail.com

Copyright: ( $)$ the author(s), publisher and licensee Medip Academy. This is an open-access article distributed under the terms of the Creative Commons Attribution Non-Commercial License, which permits unrestricted non-commercial use, distribution, and reproduction in any medium, provided the original work is properly cited.

\begin{abstract}
Self-medication is a wide spread behavior, particularly among elderly patients. Self-medication involves not only the consumption of over-the-counter products but also the re-use of formerly prescribed drugs without medical supervision. This practice may lead to severe adverse health events. Here we report a case of old female, presented with cushingoid face and hyperglycemia due to self-medication of high dose Prednisolone for longer duration. Symptomatic treatment was given to stabilize the patient. Patient was warned regarding the adverse effects of drugs and strictly advised to use medication only under medical supervision.
\end{abstract}

Keywords: Prednisolone, Hyperglycemia, Cushing disease, ADR, Self-medication

\section{INTRODUCTION}

Corticosteroids are synthetic analogues of natural steroid hormones produced by adrenal cortex. They are widely used class of drugs due to their anti-inflammatory, vasoconstrictive, anti-proliferatory and immunosuppressive effects.

They can cause adverse effects that are related to the dose and duration of therapy. ${ }^{1}$ Prolonged high doses can lead to potential adverse effects including Cushingoid habitus (moonface, central obesity), diabetogenesis, myopathy, peptic ulcer, osteoporosis, dyslipidemia, adrenal insufficiency and cardiovascular risk. ${ }^{2}$

\section{CASE REPORT}

A 55 years old female was admitted in government general hospital, Kadapa. She was presented to emergency department with complaints of shortness of breath (grade II type), abdominal distension, facial puffiness (Figure 1) since, 2 months, severe headache and giddiness. Her past history revealed that she was a known hypertension patient and was using tab nifedipine $20 \mathrm{mg}$
OD. On enquiry the patient revealed that she was on selfmedication with tab. Prednisolone $40 \mathrm{mg}$ OD for severe headache and body pains since, 1 year.

On examination she was pallor with swollen face, extremities were normal and her blood pressure was abnormal 160/90 mmHg. Laboratory findings were $\mathrm{Hb}$ $10.5 \mathrm{~g} \%$, TC-6800 cells/cu mm, RBS- $247 \mathrm{mg} / \mathrm{dl}$, platelets -1.5 lakhs, liver function test and renal function test were found to be normal. She was diagnosed as drug induced Cushingoid symptoms with hyperglycemia.

\section{Causality assessment of suspected ADR}

To evaluate the relationship between drug and reaction, we have performed causality assessment by using WHO causality assessment scale.

Table 1: WHO causality of suspected reactions.

\begin{tabular}{|lll|}
\hline S. no. & Suspected reaction & WHO causality \\
\hline 1. & Hyperglycemia & Probable \\
\hline 2. & Facial edema & Probable \\
\hline
\end{tabular}




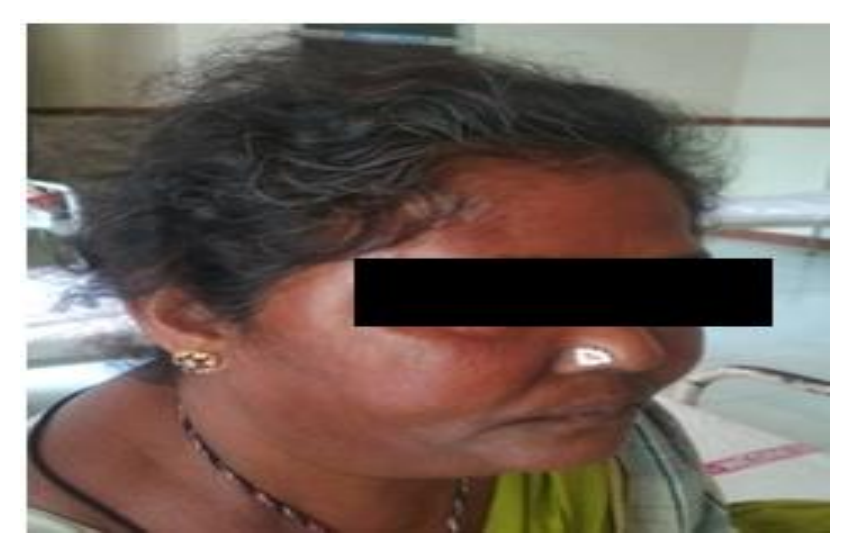

Figure 1: Facial puffiness.

\section{Outcome and follow up}

After suspecting the condition, patient was advised to stop prednisolone after tampering the dose to $10 \mathrm{mg}$ for a week. She was prescribed with hypoglycaemic agents to renormalize blood glucose levels and T. Furosemide 40 $\mathrm{mg}$ OD, T. diclofenac $50 \mathrm{mg} \mathrm{BD}$ and vitamin supplements. Patient was monitored, found to be stabilized and got discharged.

\section{DISCUSSION}

Usually elderly people have a greater tendency of selfmedication. They consume more drug products for selftreatment purposes due to their co- morbidities. In addition, physiological changes associated with aging process and variation in PK and PD process makes them more vulnerable to ADRs. ${ }^{3}$ Steroids involve in carbohydrate, lipid, and protein metabolism resulting in increased gluconeogenesis and enhanced catabolic action on muscle, skin, lymphoid, adipose, and connective tissue. High-residual secretion of hydrocortisone or decreased clearance of Prednisolone may be risks factors for corticosteroid-induced lipodystrophy and facial edema. More over corticosteroids induce an increase in the synthesis of glucose. They restore carbohydrates from amino acids by stimulating gluconeogenesis enzymes in the liver, by mobilization and degradation of proteins and by support of glycogen deposition the liver. Thus, leading to hyperglycemia. ${ }^{4,5}$

\section{CONCLUSION}

Despite of its benefits in providing medications without prescription and minimizing health care costs, selfmedication may impose complications like risk of adverse drug reactions and resistance. Awareness must be created regarding the risk of self-medication and public must be strictly educated to use medication only under medical supervision. This significantly enables us in practicing rational drug use and minimizing ADR and other drug related problems.

Funding: No funding sources

Conflict of interest: None declared

Ethical approval: Not required

\section{REFERENCES}

1. Paradkar S. Reported Adverse Drug Reactions during the Use of Corticosteroids in a Tertiary Care Hospital. Ther Innov Regul Sci. 2019;53:128-31.

2. Liu D, Ahmet A, Ward L. A practical guide to the monitoring and management of the complications of systemic corticosteroid therapy. Allergy Asthma Clin Immunol. 2013;9(1):30.

3. Locquet M, Honvo G, Rabenda V. Adverse Health Events Related to Self-Medication Practices Among Elderly: A Systematic Review. Drugs Aging. 2017;34(5):359-65.

4. Stanbury RM, Graham EM. Systemic corticosteroid therapy side effects and their management. British J Ophthalmol. 1998;82:704-8.

5. Fardet L, Kassar A, Cabane J, Flahault A. Corticosteroid-induced adverse events in adults: frequency, screening and prevention. Drug Saf. 2007;30(10):861-81 .

Cite this article as: Kalpana P. Self-care convicting adverse reaction: prednisolone instance. Int J Basic Clin Pharmacol 2020;9:1285-6. 